\title{
Tıp Veri Kümesi için Gizli Dirichlet Ayrımı
}

\section{Latent Dirichlet Allocation for Medical Dataset}

\author{
Ekin Ekinci ${ }^{*}{ }^{\oplus}$, Sevinç İlhan Omurca ${ }^{2}$, Elif Kırık ${ }^{1.2}{ }^{\oplus}$, Şeymanur Taşçı ${ }^{1}$ \\ ${ }^{1}$ Kocaeli Üniversitesi, Mühendislik Fakültesi, Bilgisayar Mühendisliği Bölümü, Kocaeli, TÜRKIYE \\ 2 Enuygun, İstanbul, TÜRKIYE \\ Sorumlu Yazar / Corresponding Author*: silhan@kocaeli.edu.tr \\ Geliş Tarihi / Received: 12.03 .2019 \\ Araștırma Makalesi/Research Article \\ Kabul Tarihi / Accepted: 20.09.2019 \\ DOI: 10.21205/deufmd 2020226408
}

Atıfssekli/How to cite: EKINCİ, E., OMURCA, S.O., KIRIK, E., TAŞÇI, S.. (2020). Tıp Veri Kümesi için Gizli Dirichlet Ayrımı. DEUFMD 22(64),67-80.

Öz

Bilimsel çalışmalarda ilgili alandaki literatürün incelenmesi oldukça önemli bir aşamadır. Literatür insan tarafından tarandığında, geniş kapsamlı bir inceleme yapılması mümkün olamamakta, ya da böyle bir arama çok uzun zaman almaktadır. Öte yandan literatürün otomatik olarak taranması derinlemesine bir anlamsal analizi mümkün kılmamaktadır. Bu çalışma kapsamında Türkiye'deki araştırmacılar tarafından yayınlanmış tıp makalelerinin otomatik ve anlamsal analizini gerçekleştiren bir konu modelleme yöntemi olan Gizli Dirichlet Ayrımı (GDA) uygulanmıştır. Deneysel çalışma, yıllara göre bir tıp veritabanı olan PubMed'den elde edilen son 11 (on bir) yıldaki yayınla tıp literatüründeki makaleler üzerinde gerçeklenmiștir. Deneysel sonuçlar incelendiğinde, son 11 (on bir) yılda trend olan çalıșma bașlıklarının bașarılı bir șekilde keșfedildiği gözlenmiștir.

Anahtar Kelimeler: Konu modelleme, Gizli Dirichlet Ayrımı (GDA), Tıp literatürü, PubMed

\section{Abstract}

Examination of the literature in the relevant field is a very important stage in scientific studies. When the literature is reviewed manually, it is not possible to perform a comprehensive review or such a search takes a very long time. On the other hand, the automatic search of the literature does not enable in-depth semantic search. In this study, a topic modelling method Latent Dirichlet Allocation (LDA), that performs the automatic and semantic analysis of medical articles published by researchers in Turkey, is applied. The experimental study was carried out on articles in the medical literature in the last 11 (eleven) years from PubMed, which is a medical database based on years. When the experimental results are analyzed, it has been observed that the titles, which have trend in the last 11 (eleven) years, have been discovered successfully.

Keywords: Topic modelling, Latent Dirichlet Allocation (LDA), Medical literature, PubMed

\section{Giriş}

Günümüzde insanların bilgiye erișiminde internetin önemi çok büyüktür. Web sayfaları, haberler, bloglar, sosyal medya platformları, eticaret siteleri, bilimsel makaleler gibi çok farklı kaynaklar her alanda bilgiye erişimi oldukça kolaylaştırmaktadır. Bunun sonucu olarak, internet kaynaklarında depolanan verinin boyutu da her geçen gün artmaktadır. Depolanan verinin çok büyük oranda metin verisi olduğu göz önüne alındığında, metin verilerinin otomatik analizi oldukça önemli bir araştırma problemi haline dönüşmektedir. Bu doğrultuda, 
DEU FMD 22(64), 67-80, 2020

genis ölçekli metin verilerinde arama, anlama ve işleme görevlerini yerine getirecek otomatik araçlara ihtiyaç ortaya çıkmıştır. $\mathrm{Bu}$ boşluğu doldurmak için konu modelleme yöntemleri; makine öğrenmesi, doğal dil işleme ve bilgi çıkarımı süreçlerinde yaygın şekilde uygulanmaya bașlanmıștır. Konu modelleme, geniş ölçekli doküman koleksiyonlarından anlamsal bilgiye erișimde uygulanan denetimsiz bir makine öğrenmesi yöntemidir. Literatürde, araştırmacılar tarafından geliștirilen mevcut pek çok konu modeli bulunmaktadır. Bu konu modelleri arasında en yaygın ve tam olanı Gizli Dirichlet Ayrımı (GDA)'dır [1-4]. Dokümanlar gibi ayrık verileri modellemek için geliştirilen üretici grafiksel bir model olan GDA dokümanı olușturan gizli konuları ortaya çıarmaktadır [5]. GDA'nın dayandığı temel fikir, konuların sabit bir sözlük üzerinden olasılık dağılımına sahip olması ve dokümanların gizli konuların rastgele bileşiminden oluşmasıdır. $\mathrm{Bu}$ temel fikre göre GDA, doküman koleksiyonundaki konuları, konuları oluşturan kelimelerin konular altındaki olasılıklarını, dokümanlar için o dokümanı oluşturan kelimelerin hangi konulara atandığını ve her doküman için bu dokümandaki konuların dağılımını öğrenmektedir [6].

Tıp alanındaki çevrimsel araştırmalar, temel laboratuvar bilimini etkili hasta terapilerine mümkün olduğunca çabuk dönüştürmekle ilgilidir. Etkili tedavilerin geliştirilmesi, fizyolojik, hücresel ve moleküler düzeyde tıp, farmakoloji, biyoloji ve kimya disiplinler arası bir anlayıș gerektirir. Örneğin, biyomedikal alanda kimyasallar, genler ve hastalıklar arasındaki ilișkilerin hızlı bir șekilde keșfi, ilaç keşifleri gibi araştırmalarda çok değerlidir. Bugünün tıp doktorları ve biyomedikal araştırmacıları, çeşitli kaynaklardan giderek artan miktarda yüksek boyutlu, heterojen ve karmaşık verilerle karşı karşıya kalmaktadır [7]. Özgün çalıșmaların gerçekleștirilebilmesi için bu çeşitli alanlarda yayınlanmış literatürün derinine incelenmesi önem arz etmektedir. Bunun yanı sıra karmaşık disiplinler arası araştırmalar, yayınlanmış literatürde yer alan en son bilgileri, eğilimleri ve bulguları makul bir süre içinde verimli bir şekilde keşfetmeyi, değerlendirmeyi ve sentezlemeyi zorlaştırmaktadır. Bu nedenle, özetlerin ve tam metinli dergi makalelerinin sistematik analizi yoluyla bilgi keşfini kolaylaștırmak için yararlı yaklaşımlar üretmek önemli ve devam eden bir sorun haline gelmiștir. Bu çalışmada, Türkiye'de tıp alanındaki araștırmacılar için hangi konularda daha aktif çalışıldığını saptamanın yaralı olacağı düşünülerek; tıp alanında son 11 (on bir) yılda trend olan konu bașlıklarının otomatik olarak keşfedilmesi sağlanmıştır. Bunun yanı sıra yıl bazında trend olan çalışma konuları kolayca keșfedilebilmekte ve bu konularda yayınlanan belirgin makalelerin otomatik ve kolay erișimi de sağlanabilmektedir.

Makalenin geri kalan kısmı; ikinci bölümde mevcut çalışmalar, üçüncü bölümde deneysel yöntemin, GDA ve hata analizi başlıkları altında ayrıntılı şekilde incelenmesi; dördüncü bölümde veri kaynaklarının elde edilmesi ve bu veri kaynaklarına yapılan önişleme adımlarının, yapılan parametre ayarlarının ve deneysel çalışmanın anlatılması ve son olarak da tartışma ve sonuçlar şeklinde verilmiştir.

\section{Mevcut Çalışmalar}

PubMed, dergilerde ve kitaplarda yayınlanan makaleler için 28 (yirmi sekiz) milyondan fazla alıntı sağlayan çevrimiçi bir kaynaktır ve çoğu kısa özetlerle ilișkilendirilirken, giderek artan sayıda ücretsiz tam metin makalelerine de erişilebilmektedir. $\mathrm{Bu}$ çalışma kapsamında literatüre erișim PubMed veri tabanı üzerinden gerçekleștirilmiștir. Mevcut literatür incelendiğinde benzer çalışmaların yer aldığı gözlenmiștir.

[8] nörobilimin genel bir analizini elde etmek için 2001-2006 yılları arasında Society for Neuroscience (SFN) yıllık toplantı özetlerinden özet metinleri elde edip bu metinleri işlemişlerdir. Doğal dil işleme, metin madenciliği ve diğer veri analizi tekniklerini kullanarak, bilimsel işbirliği ağının demografik ve yapısını, zaman içindeki alanın dinamiklerini, araștırma eğilimlerini incelemişlerdir. Elde ettikleri SFN özet kümesinin içerdiği konu başlıklarını tanımlamak için Gizli Anlamsal Analiz (GAA) yöntemini kullanmışlardır.

[9] PubMed veri tabanındaki özetleri kullanarak kelimeler, MeSH terimleri, dokümanlar ve konu başlıkları arasındaki ilişkileri keşfetmek için Topic-concept model adını verdikleri bir konu modelleme yaklaşımı önermişlerdir. [10] 2647 diyabet hastasına ait vakaları incelemek üzere LinkLDA modeli önermișlerdir. Hastalığa ait bazı semptomlara ve bu semptomları tedavi edebilecek bazı bitkilere ait konu başlıkları keşfetmeyi hedeflemişlerdir. 
DEU FMD 22(64), 67-80, 2020

[11] elektronik hasta kayıtlarını analiz etmek için konu modelleme, temel bileşenler analizi ve ikili kümeleme tekniklerini uygulamışlardır. Hastalara ait kanser kayıtlarına ve kanserle ilişkili olabilecek biyolojik etkenleri keşfetme konusuna odaklanmışlardır. [12] son 5 (beş) yıl içinde artış gösteren 5 (beş) farklı kanser türü hakkındaki anahtar konu başlıklarının çıkarılması için biyomedikal literatürüne GDA algoritmasını uygulamışlardır. GDA parametrelerinin güncellenmesini Gibbs örnekleme yöntemi ile gerçekleştirmişlerdir.

[13] hiyerarşik Dirichlet süreci kullanarak konuları otomatik olarak çıkartan bir yapı önermişlerdir. Sonrasında çıkan konular arasında bir ilișki ağı olușturmușlardır. Modelin etkinliğini kanıtlamak için 18.000 dokümandan oluşan autism spectrum disorder (ASD) literatürünü kullanmışlardır. [14] Alzheimer hastalığına ait literatürü incelemek için PubMed veri tabanında de yayınlanan 96.081 makale üzerinde "concept graph-based network analysis" yaklaşımı ile bir inceleme gerçekleştirmişlerdir. Aynı zamanda zamana bağlı trend konu çıkarımını "Dirichlet multinomial regression topic modeling" yöntemi ile gerçekleştirmişlerdir. 2013 yılının bu alanda en çok yayın yapılan yıl olduğu sonucuna varmıșlardır. [15] PubMed ve PubMed Central veritabanlarından elde ettikleri geniş ölçekli biyomedikal yayınlar üzerinde GDA yöntemini büyük veri kavramı ile ilgili başlıkları keşfetmek üzere uygulamışlardır. Sonrasında 7 (yedi) uzman kişi, model tarafından çıkarılan başlıkları büyük veri tanımları ile eşleştirmiştir.

[16] Konu modelleme yöntemlerini kullanarak, serbest metinler olarak yazılmış klinik dokümanlardan klinik kavramları temsil eden kelime öbeklerini keşfetmeyi amaçlamışlardır. [17] 1998-2016 yılları arasında yayınlanmış biyoinformatik literatürünü analiz etmek için konu modelleme yaklaşımını kullanmışlardır. Her yıla ait en yaygın kullanılmış olan anahtar kelimeler analiz edilmiş ve sonrasında daha detaylı analiz için konular otomatik olarak keşfedilmiştir. Çalışmaları sonucunda kanser alanında büyük veri tekniklerini kullanarak çözüm arayan araştırmaların son yıllarda artış gösterdiği sonucuna varmıșlardır.

[18] PubMed veritabanında 2016 ve 2017 yılları arasında yayınlanmış olan sadece elektronik sağlık literatürüne ait trend konuları keşfetmek üzere klasik GDA yöntemini kullanmışlardır. Bu
Yaptıkları çalıșma ile, elektronik sağlık alanda hangi konuların bir yıl içerisinde pozitif trend hangilerinin ise negatif trend gösterdiği tespit edilmiştir.

Biyomedikal literatürün analizine ilişkin çalışmalar incelendiğinde, araştırma makalelerinde, disiplinler arası işbirliklerinden dolayı giderek artan bir konu karmaşıklığı olduğu açlktır. $\mathrm{Bu}$ durum da, biyomedikal metinlerde birlikte ya da sık çalışılan konu başlıklarının belirlenmesini zorlaştırmaktadır. Bildiğimiz kadarı ile Türkiye'de tıp alanında yayınlanmış bilimsel makalelerden otomatik konu keşfeden bir çalışma yer almamaktadır. Çalışmamız bu anlamda gerçekleştirilen ilk çalışmadır. Ayrıca 2007-2017 yılları arasında yayınlanmış olan makalelerin incelendiği göz önüne alındığında oldukça geniş kapsamlı bir analiz gerçekleştirilmiştir.

\section{Materyal ve Metot \\ 3.1. Gizli dirichlet ayrımı}

Doküman koleksiyonlarındaki gizli tematik bilgiyi küçük boyutlu uzaya çevirerek keşfeden bir grup algoritma olarak tanımlanan olasılıksal konu modelleri son yıllarda makine öğrenmesi ve metin madenciliği alanlarında büyük önem kazanan araştırma konularından birisi haline gelmiştir [5,19-21]. Bu yöntemler altında yatan temel fikir kelimeler üzerinde olasılık dağılımı gösteren konuların rastgele bir araya gelerek dokümanları oluşturması şeklinde açıklanmaktadır [21]. Konu ise dokümanda tartışılan temel fikirdir yani dokümanın temasidır.

Konu modelleme yöntemleri üzerine literatürde pek çok başarılı çalışma olmakla birlikte, hala daha teorikte anlaşılması güç bir konu olarak karşımıza çıkmaktadır. Konu modelleri ilk olarak [22] tarafından geliştirilen GAA yöntemi ile ortaya çıkmıştır. GAA'da doküman koleksiyonundaki gizli anlamsal ilişkiler keşfedilip düşük boyutlu anlamsal bir uzay elde etmek amaciyla doküman terim matrisi üzerinden tekil değer ayrıșımı uygulanmaktadır. GAA'nın olasılık tabanlı formu olarak 1999 yılında geliştirilen Olasılıksal Gizli Anlamsal Analiz (Olasılıksal GAA) üretici grafiksel bir konu modelidir [23]. Olasılıksal GAA dokümanların gizli konuların rastgele bir araya gelerek dokümanı oluşturduğu fikrine dayalı ilk yöntemdir. Model sadece kelime seviyesinde bir olasılık modeli sunmaktadır bu da modelin tam 
DEU FMD 22(64), 67-80, 2020

bir üretici model olmasını engellemektedir. Ayrıca aşırı öğrenmeye eğilimi olması ve yeni gördüğü dokümanlar üzerinde genelleme yapamaması modelin dezavantajlarıdır [24]. [5] tarafından geliştirilen Gizli Dirichlet Ayırımı (GDA) kelimelerin konulardaki, konuların da dokümanlardaki dağılımını Dirichlet dağılımından elde ederek Olasılıksal GAA yöntemini geliştirip tam bir üretici modeli sunmaktadır.

GDA, doküman gibi ayrık verileri modellemek ve dokümanı oluşturan gizli konuları ortaya çıkarmak için geliștirilmiş üretici grafiksel bir modeldir [5]. GDA'daki gizli dokümanı olușturan gizli konuları tanımlamaktadır. Dirichlet dağılımı Beta dağılımının çok değișkenli versiyonu olup, bir simpleks ile sınırlandırılmıș rastgele vektörler için çok değişkenli bir dağılım olarak tanımlanmaktadır [25]. Tamamen denetimsiz bir yöntem olan GDA herhangi bir önbilgiye ihtiyaç duymaz. Kelime torbası yaklaşımına dayalı yöntemde kelimelerin doküman içerisindeki yerleşimi göz ardı edilmekte, kelimelerin birlikte bulunması ise göz önünde bulundurulmaktadır. GDA'nın üretici bir model olması demek basit bir olasılıksal süreç ile dokümandaki kelimelerin rastgele değișkenler ile oluşturulmasıdır, yani dokümanın oluşturulmasıdır [19]. GDA için üretici model Şekil 1'de verilmiştir.

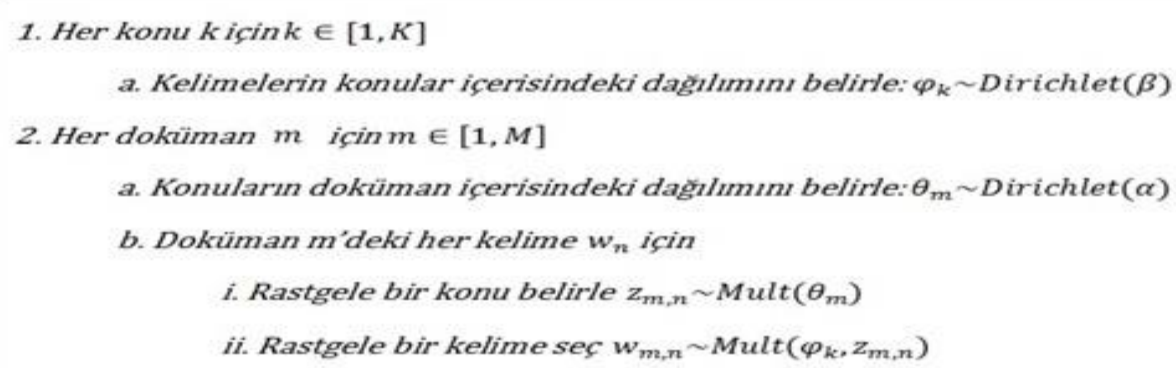

Şekil 1. GDA için üretici model [26]

Üretici model ilk olarak doküman koleksiyonu içerisindeki tüm kelimeleri kapsayan sabit bir sözlük olan V'nin bütün konular içerisindeki dağılımını Dirichlet dağılımına göre belirler. Toplam K konu içerisinden k. konudaki kelimelerin dağılımı $\varphi_{\mathrm{k}}$ ile temsil edilir ve $\varphi_{\mathrm{k}}$ Dirichlet parametresi olan $\beta^{\prime}$ ya göre hesaplanır. İkinci adımda toplam boyutu $\mathrm{M}$ olan koleksiyondaki her doküman $\mathrm{m}$ için ilk olarak Dirichlet parametresi olan $\alpha$ 'ya göre konuların doküman içerisindeki dağılımı $\theta_{\mathrm{m}}$ belirlenir. Toplamda $\mathrm{N}_{\mathrm{m}}$ tane kelime içeren $\mathrm{m}$ dokümanındaki her kelime wm,n için bu kelimenin konusu zm,n çok terimli dağılıma göre örneklenir. Son olarak da yine çok terimli dağılıma göre ilgili konu için rastgele bir kelime örneklenir.
GDA aynı zamanda grafiksel bir modeldir ve grafiksel temsilinde plate notasyonu kullanılmaktadır. Plate notasyonu aynı tipte birden fazla nesnenin olduğu durumlar için kullanılmaktadır. Plate notasyonu GDA'da ise gözlemlenen verinin gizli değişkenler ve bu gizli değişkenlerin yönlü kenarlar üzerinden yayılımı ile nasıl üretildiğini göstermek amacıyla kullanılmaktadır [27]. Burada gözlemlenen veriler ile kastedilen dokümanı olușturan kelimeler iken, gizli değişkenler ile kastedilen ise kelimelerin konulardaki dağılımı, konular ve konuların dokümandaki dağılımıdır. GDA'ya ait plate notasyonu Şekil 2'de verilmiștir. Grafiksel modelde gözlemlenen değișkenler gri renkle temsil edilirken gizli değişkenler beyaz renk ile temsil edilmiştir. 


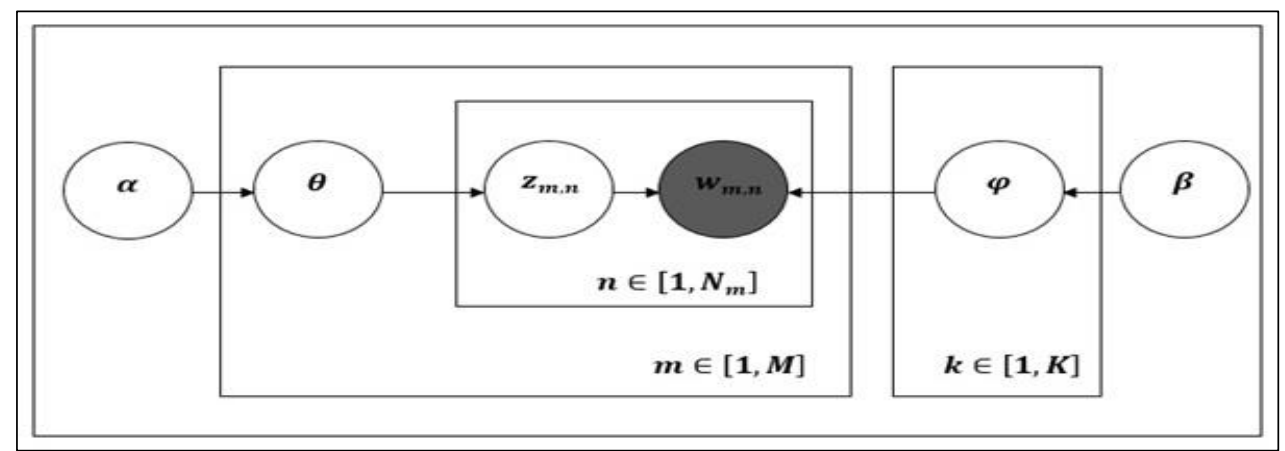

Şekil 2. GDA'ya ait plate notasyonu [28]

Şekil 2'deki grafiksel modele göre gözlemlenen ve gizli değişkenlere için bileşik dağılımı $p\left(\varphi_{1: K}, \theta_{1: M}, z_{1: M}, w_{1: M}\right) \quad$ Denklem $\quad 1$ 'de verilmiştir.

$$
\begin{aligned}
& \left(\prod_{k=1}^{K} p\left(\varphi_{k} \mid \beta\right)\right)\left(\prod_{m=1}^{M} p\left(\theta_{m} \mid \alpha\right)\right) \\
& \left(\prod_{n=1}^{N_{m}} p\left(z_{m, n} \mid \theta_{m}\right)\left(w_{m, n} \mid z_{m, n}, \varphi_{k}\right)\right)
\end{aligned}
$$

GDA'nın hedefi gizli değişkenlerin elde edilmesidir. Gizli değişkenlerin $p\left(\varphi_{1: K}, \theta_{1: M}, z_{1: M} \mid w_{1: M}\right) \quad$ elde edilmesinde Denklem 2 kullanılmaktadır.

$$
\frac{p\left(\varphi_{1: K}, \theta_{1: M}, z_{1: M}, w_{1: M}\right)}{p\left(w_{1: M}\right)}
$$

Denklem 2'deki payın tüm rastgele değişkenlerin birleşik dağılımı olduğu ve kolayca hesaplanabileceği görülmektedir. Ancak payda gözlemlerin marjinal olasılı̆̆ıdır dolayısıyla bu olasılık doküman kümesinin herhangi bir konu modeli altındaki olasılığını ifade etmektedir. Hesaplanabilmesi için de gizli konu yapısının tüm örnekleri üzerinden birleşik dağılımı toplamak gerekmektedir. Yalnız bu toplamın hesaplanması mümkün konu yapısının oldukça fazla olmasından ötürü mümkün değildir. Bu nedenle sonsal dağılıma yakınsamak için örnekleme algoritmalarından yararlanılmaktadır. GDA için kullanılan örnekleme algoritması ise Gibbs örneklemenin standart bir gerçekleştirimi olan Collapsed Gibbs Örnekleme (CGÖ)'dir.
Griffiths ve Steyvers tarafından önerilen CGÖ model parametreleri olan $\theta$ ve $\varphi^{\prime}$ yi dișarlamakta, kelimelere konu atamada kullanılan parametre z önce dokümandaki her kelime için daha sonra koleksiyonundaki diğer tüm dokümanlarda yer alan kelimeler için iteratif olarak yeniden örneklenmektedir [29]. CGÖ'de model parametreleri dışarlandığ 1 için koleksiyonundaki kelimelerin konulara atanmasında diğer kelimeler model parametrelerinin vekili olarak kullanılmaktadır. Örnekleme ile belli bir kelimenin hangi konuya atanacağı Denklem 3 ile hesaplanmaktadır.

$$
\begin{aligned}
& p\left(z_{i}=k \mid w_{i}=v, m, \alpha, \beta, .\right) \\
& =\frac{n_{v, k}+\beta}{\sum_{w \in V} n_{w, k}+V \beta} \frac{n_{m, k}+\alpha}{N_{m}-1+\alpha K}
\end{aligned}
$$

Denklem 3'ün sol tarafında $w_{i}, m, \alpha$ ve $\beta$ diğer tüm kelimelerin hangi konuya atanmış oldukları ( $\because$ ' ile temsil ediliyor) biliniyor iken $\mathrm{z}_{\mathrm{i}}=\mathrm{k}$ olma olasılığı bulunmaktadır. Eşitliğin sağ tarafında ise $\mathrm{n}_{\mathrm{v}, \mathrm{k}}$ ile $\mathrm{v}$ kelimesinin $\mathrm{k}$. konuya tüm koleksiyonda kaç kere atandığı hesaplanmakta, $\mathrm{n}_{\mathrm{w}, \mathrm{k}}$ k. konunun tüm koleksiyonda kaç kere kullanıldığını göstermekte, $\mathrm{n}_{\mathrm{m}, \mathrm{k}} \mathrm{m}$. yorumda $\mathrm{k}$. konuya atanan kelime sayısını temsil etmektedir. Başlangıç değerleri kullanılarak Denklem 3 doküman koleksiyonundaki tüm dokümanlardaki tüm kelimeler için yapıldıktan sonra $\theta$ ve $\varphi$ değerleri Denklem 4 ve Denklem 5 'e göre güncellenmektedir.

$$
\begin{aligned}
\varphi_{v, k} & =\frac{n_{v, k}+\beta}{\sum_{w \in V} n_{w, k}+V \beta} \\
\theta_{m, k} & =\frac{n_{m, k}+\alpha}{N_{m}-1+\alpha K}
\end{aligned}
$$


DEU FMD 22(64), 67-80, 2020

\subsection{Hata analizi}

GDA ile elde edilen konuların kendi içlerindeki anlamsal uyumluluğunu ölçmek amacıyla konu uyumluluğu ölçütünden yararlanılmaktadır [30]. Konu uyumluluğu bir konuyu oluşturan sözcükler arasındaki ortalama anlamsal ilișki olarak tanımlar [31]. Konu uyumluluğu Denklem 6'ya göre hesaplanmaktadır.

$$
\begin{aligned}
& C\left(k ; V^{k}\right) \\
& =\sum_{n=2}^{N} \sum_{l=1}^{n-1} \log \frac{D\left(v_{n}^{(k)}, v_{l}^{(k)}\right)+1}{D\left(v_{l}^{(k)}\right)}
\end{aligned}
$$

$\mathrm{V}^{(\mathrm{k})}=\left(\mathrm{V}_{1}{ }^{(\mathrm{k})}, \ldots, \mathrm{V}_{\mathrm{S}}(\mathrm{k})\right) \mathrm{k}$. konudaki en mümkün $\mathrm{S}$ kelimenin listesidir. $\mathrm{D}\left(\mathrm{v}_{\mathrm{n}}{ }^{(\mathrm{k})}, \mathrm{V}_{\mathrm{l}} \mathrm{k}^{(\mathrm{k})}\right) ; \mathrm{V}_{\mathrm{n}}$ ve $\mathrm{vl}_{\mathrm{l}}$ kelimelerinin birlikte geçtiği doküman sayısıdır. 1 ise yumuşatma için kullanılmıştır. $\mathrm{D}\left(\mathrm{vl}_{\mathrm{l}} \mathrm{k}^{\mathrm{k})}\right)$, vı́nin tüm koleksiyondaki frekansıdır. Yüksek konu uyumluluğu modelin başarılı olduğunu göstermektedir.

\section{Bulgular}

\subsection{Veri kaynakları ve önişleme}

$\mathrm{Bu}$ çalışmada kullanılan veri kümesi PubMed Biyomedikal Veritabanı kaynağından elde edilen İngilizce makalelerden oluşturulmuştur. Ülkemizde çalışılan alanların tespit edilmesini amaçladığımız için de makalelerin tünü Türkiye'de bulunan doktorlara aittir. PubMed, ücretsiz bir biyomedikal veritabanıdır. Sitede yer alan başvuru kitapları moleküler biyoloji, genetik ve tıp bilimleriyle ilgili konulara ışık tutmaktadır. PubMed, biyomedikal literatür için MEDLINE'dan 20 (yirmi) milyondan fazla atıf bilgisi ile yaşam bilimleri dergileri ve çevrimiçi kitapları içermektedir. PubMed ayrıca ilișkili web sayfaları ile NCBI (National Center for Biotechnology Information)'un diğer moleküler biyoloji kaynaklarına erişim sağlayıcı bağlantılar sunmaktadır.

Veri kaynaklarının eXtensible Markup Language (XML) formatında elde edilmesinde açık kaynak bir veri analizi, raporlama ve uyum platformu olan Konstanz Information Miner (KNIME) kullanılmıştır [32]. Verinin XML formatında elde edilmesinin amacl ise verileri kolayca erişilebilecek ve paylaşılabilecek bir biçimde saklamasıdır. KNIME ile çekilen verilerin formatına bir örnek Şekil 3'te verilmiştir.

Veri kümesi 2007-2017 yılları arasında yayınlanmış makalelerin özetlerini içermektedir ve yıllara göre makale sayıları Tablo 1.'de özetlenmektedir.

Tablo 1. Yıllara göre elde edilen makale sayıları.

\begin{tabular}{ll}
\hline Yll & Elde Edilen Makale Sayısı \\
\hline 2007 & 10502 \\
2008 & 10806 \\
2009 & 10807 \\
2010 & 10900 \\
2011 & 11864 \\
2012 & 13362 \\
2013 & 15044 \\
2014 & 16814 \\
2015 & 18348 \\
2016 & 18080 \\
2017 & 15698 \\
\hline
\end{tabular}

İnternet üzerindeki veriler kolay elde edilebilir olmalarına karşın kolayca kullanılabilecek bir formata sahip olmayabilirler. $\mathrm{Bu}$ durumda verilerin uygun formlara dönüştürülmeleri için ön işleme adımlarının uygulanması gerekmektedir. Çalışmamızda gerçekleştirilen ön işleme adımları sırası ile şu şekilde gerçekleştirilmiştir: (I) Model büyük küçük harf duyarlı olmadığı için ilk olarak metinlerdeki verilerin hepsi küçük harfe çevrilmiştir. (II) Sonrasında küçük harfe çevrilen metin verileri birimlendirici ile birimlerine ayrılmıștır. (III) Metinlerdeki tüm noktalama işaretleri konuların çlkartılmasında bir anlam ifade edilmediği için kaldırılmıştır. (IV) İngilizce doğal dil işlemede durak kelimeleri olarak listelenen kelimeler (the, am, who, ...) çıkartılmış ve doğal dil işleme aracı olan Natural Language Toolkit (NLTK)'nın durak kelime temizleme modülü olan stopword modülü ile metinler bu kelimelerden temizlenmişlerdir. (V) Son olarak modelin doğru çalışabilmesi için kelimeler gövdelemeye tabii tutulmuşlar ve yine NLTK'nın sunmuş olduğu WordNetLemmatizer modülü bu aşamada kullanılmıştır. NLTK doğal dildeki metinleri işleyen Python için geliştirilmiş bir kütüphanedir. 


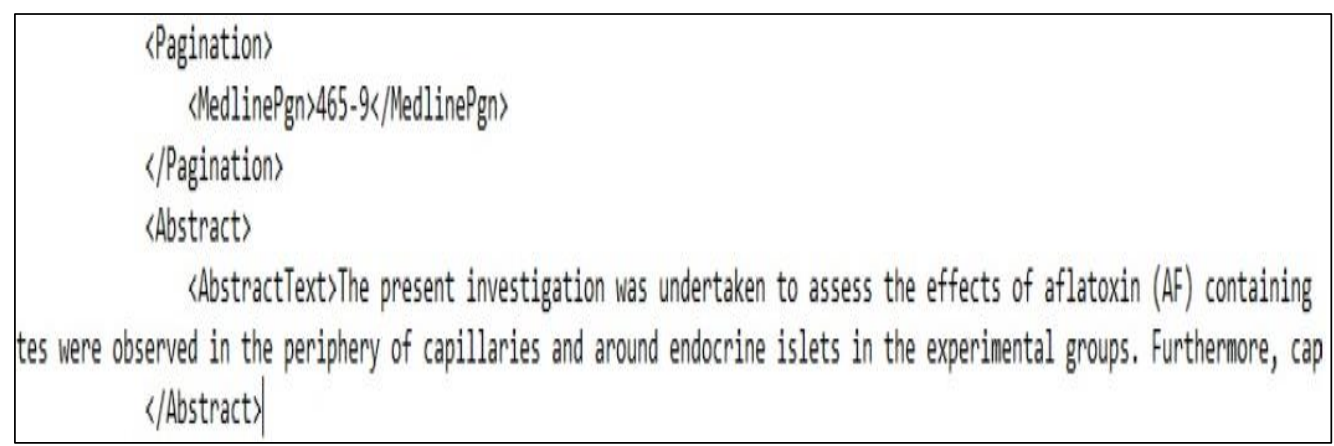

Şekil 3. Veri formatı örneği

\subsection{Parametre ayarları}

GDA için Gibbs örnekleme 50, 100, 200, 500 ve 1000 iterasyonda çalıștırılmıștır. K ile temsil edilen konu sayısı 20 (yirmi) olarak belirlenmiștir. Dirichlet hiperparametreleri $\alpha$ ve $\beta$ sirasiyla $50 / \mathrm{K}=2.5$ ve 0.01 olarak belirlenmiştir. Model parametreleri metin sayısı ile toplam kelime sayısının çarpımı kadar güncellenmektedir. Çıkartılan her konu ise ilk 10 (on) kelimesiyle temsil edilmiştir. Her yıl için 20 (yirmi) konudan anlamlı olma durumlarına göre 4 (dört) ya da 5 (beş) tanesi o yılı temsil etmek için seçilmiştir.

\subsection{Deneysel sonuçlar}

$\mathrm{Bu}$ çalışma kapsamında GDA farklı sayılarda metinlerden oluşan 11 farklı veri kümesine uygulanmıș ve sonuçlar hem niceliksel hem de niteliksel olarak değerlendirilmiştir. Niceliksel değerlendirmede konu uyumluluğu ölçütünden yararlanılmışken, niteliksel değerlendirme için uzman tıp doktoru konuların geçerliliğini kontrol etmiș ve konu etiketlerini belirlemiștir. Böylece yıllara göre hangi konular üzerine araştırmalar yapıldığı ve hangi konuların popüler olduğu belirlenmiştir.

Modelin yıllara göre elde edilen ortalama konu uyumluluğu iterasyon sayısına bağlı olarak Şekil 4'te verilmiştir.

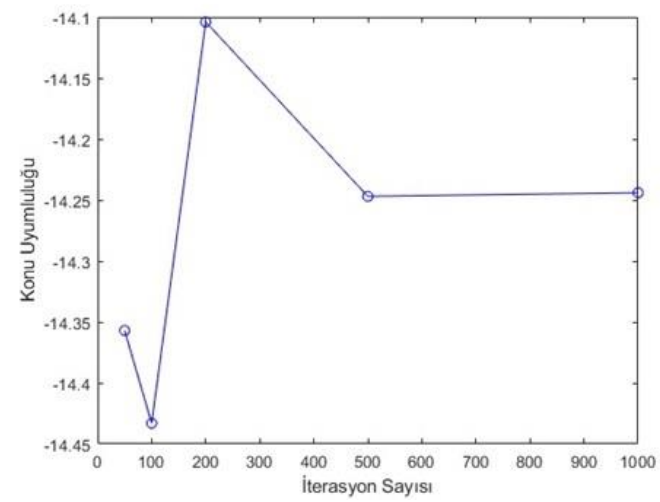

Şekil 4. İterasyon sayısına göre ortalama konu uyumluluğu

Şekil 4 incelendiğinde modelin konu uyumluluğu açısından en başarılı olduğu iterasyon sayısının 200 olduğu görülmektedir. -14.244 konu uyumluluğu ile 1000 iterasyon ikinci sırada yer almaktadır. Ancak GDA değerlendirilirken genelde 1000 iterasyon sonucunda elde edilen konu uyumluluğu ve konular dikkate alınmaktadır. $\mathrm{Bu}$ nedenle niteliksel değerlendirmeler 1000 iterasyona göre yapılmıştır. Modelin yıllara göre niteliksel olarak değerlendirilmesi Tablo 2, Tablo 3, Tablo 4, Tablo 5, Tablo 6, Tablo 7, Tablo 8, Tablo 9, Tablo 10, Tablo 11 ve Tablo 12 'de verilmiştir. 
DEU FMD 22(64), 67-80, 2020

Tablo 2. 2007 yılına ait konular.

\begin{tabular}{lllll}
\hline Nöroloji & Plazma Sonuçları & Burun Hasarı & $\begin{array}{l}\text { Türkiye'deki } \\
\text { Virüsler }\end{array}$ & $\begin{array}{l}\text { Akciğer veya Böbrek } \\
\text { Komplikasyonları }\end{array}$ \\
\hline nerve & $\mathrm{p}$ & technique & Turkey & complication \\
muscle & control & surgical & population & blood \\
type & risk & procedure & data & injury \\
h & serum & surgery & region & undergo \\
spinal & high & graft & sequence & mortality \\
area & factor & perform & virus & pulmonary \\
positiom & v & flap & gene & hospital \\
pylorus & o001 & defect & identify & rate \\
side & subject & nasal & Turkish & time \\
hip & plasma & fracture & country & renal \\
\hline
\end{tabular}

Tablo 3. 2008 yılına ait konular.

\begin{tabular}{|c|c|c|c|c|c|}
\hline $\begin{array}{l}\text { Kalp Damar } \\
\text { Cerrahisi }\end{array}$ & Göğüs Kanseri & Gebelik & $\begin{array}{l}\text { Çocuklarda } \\
\text { Yașı }\end{array}$ & Kemik & Genetik \\
\hline leave & tumor & value & child & & gene \\
\hline artery & cancer & rate & test & & isolate \\
\hline nerve & stage & number & bone & & infection \\
\hline right & survival & first & year & & mutation \\
\hline coronary & garde & pregnancy & find & & polymorphism \\
\hline graft & carcinoma & two & clinical & & frequency \\
\hline verticular & breast & phase & age & & strain \\
\hline flap & median & observe & disease & & find \\
\hline defect & thyroid & find & include & & genotype \\
\hline cardiac & metastasis & increase & evaluate & & activity \\
\hline
\end{tabular}

Tablo 4. 2009 yılına ait konular.

\begin{tabular}{llll}
\hline Genetik & Gögüs Kanseri & Ortopedik Operasyon & Farelerle İlgili Çalışma \\
\hline gene & tumor & bone & rat \\
frequency & cancer & $\mathrm{mm}$ & effect \\
polymorphism & case & technique & activity \\
mutation & primary & measurement & control \\
protein & woman & fracture & tissue \\
population & breast & degree & increase \\
genotype & carcinoma & lateral & injury \\
risk & survival & measure & decrease \\
factor & stage & implant & stress \\
expression & thyroid & mean & liver
\end{tabular}


DEU FMD 22(64), 67-80, 2020

Tablo 5. 2010 yllına ait konular.

\begin{tabular}{|c|c|c|c|c|c|}
\hline $\begin{array}{l}\text { Farelerle } \\
\text { Çalıșma }\end{array}$ & İlgili & Göğüs Kanseri & Genetik & Gebelik, Çocuklar & Cerrahi Çalışma \\
\hline rat & & cell & gene & woman & case \\
\hline effect & & cancer & frequency & pregnancy & diagnosis \\
\hline increase & & expression & protein & weight & lesion \\
\hline control & & tumor & polymorphism & first & examination \\
\hline activity & & tissue & method & age & present \\
\hline decrease & & breast & genotype & infant & rare \\
\hline day & & carcinoma & investigate & period & surgery \\
\hline tissue & & stage & dna & early & imaging \\
\hline liver & & show & complex & high & mass \\
\hline stress & & lung & find & week & undergo \\
\hline
\end{tabular}

Tablo 6. 2011 yılına ait konular.

\begin{tabular}{lllll}
\hline Kalp damar cerrahi & $\begin{array}{l}\text { Ortopedik } \\
\text { operasyon }\end{array}$ & $\begin{array}{l}\text { Türkiye'deki gen } \\
\text { çalıșması }\end{array}$ & $\begin{array}{l}\text { Göğüs kanserinin } \\
\text { görüntülenmesi }\end{array}$ & $\begin{array}{l}\text { Kronik böbrek } \\
\text { hastalığ }\end{array}$ \\
\hline case & mm & gene & tumor & disease \\
complication & bone & isolate & diagnosis & renal \\
report & fracture & sample & cancer & chronic \\
present & measurement & turkey & lesion & acute \\
surgical & implant & infection & case & b \\
surgery & image & strain & mass & cell \\
artery & technique & mutation & diagnose & infection \\
procedure & type & test & breast & antibody \\
leave & root & detect & imaging & positive \\
right & mean & identify & examination & liver \\
\hline
\end{tabular}

Tablo 7. 2012 yılına ait konular.

\begin{tabular}{lllll}
\hline Genetik ve gebelik & $\begin{array}{l}\text { Enfeksiyon } \\
\text { hastalıları }\end{array}$ & $\begin{array}{l}\text { Yeni doğanlarda } \\
\text { solunum yetmezliği }\end{array}$ & $\begin{array}{l}\text { Gögüs kanseri ve } \\
\text { tiroit }\end{array}$ & $\begin{array}{l}\text { Mikrobiyolojik } \\
\text { ajanların boyanması }\end{array}$ \\
\hline $\begin{array}{l}\text { Turkey } \\
\text { frequency }\end{array}$ & mortality & cancer & isolate \\
region & data & tumor & test \\
mutation & specie & pulmonary & breast & infection \\
polymorphism & virus & infant & stage & sample \\
risk & country & early & survival & detect \\
control & period & diagnosis & method \\
genotype & population & rate & metastasis & strain \\
association & sequence & unit & carcinoma & positive \\
pregnancy & identify & failure & thyroid & find \\
\hline
\end{tabular}


DEU FMD 22(64), 67-80, 2020

Tablo 8. 2013 yılına ait konular.

\begin{tabular}{|c|c|c|c|c|}
\hline Plastik Cerrahi & $\begin{array}{l}\text { Türkiye'deki } \\
\text { enfeksiyon } \\
\text { hastalıkları }\end{array}$ & $\begin{array}{l}\text { Görüntüleme } \\
\text { yöntemleri }\end{array}$ & Cerrahi çalışma & $\begin{array}{l}\text { Farelerle ilgili } \\
\text { çalıșma }\end{array}$ \\
\hline procedure & infection & find & fracture & rat \\
\hline technique & isolate & lesion & bone & activity \\
\hline perform & Turkey & imaging & nasal & effect \\
\hline graft & sample & examination & Side & control \\
\hline complication & strain & reveal & range & increase \\
\hline skin & test & loss & nerve & stress \\
\hline day & positive & present & type & decrease \\
\hline defect & detect & normal & right & tissue \\
\hline ii & $\mathrm{b}$ & image & surgery & oxidative \\
\hline flap & specie & magnetic & anterior & antioxidant \\
\hline
\end{tabular}

Tablo 9. 2014 yllına ait konular.

\begin{tabular}{lllll}
\hline $\begin{array}{l}\text { Cerrahi teknik } \\
\text { sonrası ağrı }\end{array}$ & $\begin{array}{l}\text { Öğrencilerde } \\
\text { depresyon }\end{array}$ & $\begin{array}{l}\text { Farelerle ilgili } \\
\text { çalsșma }\end{array}$ & Kardiyoloji & Kanser \\
\hline surgery & health & rat & leave & tumor \\
postoperative & disorder & effect & artery & cancer \\
pain & data & activity & blood & stage \\
time & scale & control & pressure & survival \\
procedure & student & increase & function & treatment \\
undergo & depression & decrease & heart & grade \\
complication & care & day & cardiac & month \\
surgical & research & c & measure & primary \\
technique & Turkish & tissue & increase & carcinoma \\
perform & participant & liver & ventricular & median \\
\hline
\end{tabular}

Tablo 10. 2015 yılına ait konular.

\begin{tabular}{lllll}
\hline Gen mutasyonları & $\begin{array}{l}\text { Türkiye'de yapılan } \\
\text { çalışmalarla ilgili bir } \\
\text { özet }\end{array}$ & Göğüs kanseri & $\begin{array}{l}\text { Vaka (nadir } \\
\text { görülen) çalışması }\end{array}$ & $\begin{array}{l}\text { Cerrahi teknik } \\
\text { sonrası ağrı }\end{array}$ \\
\hline review & cancer & case & pain \\
expression & report & tumor & report & surgery \\
mutation & country & lesion & present & procedure \\
isolate & research & breast & rare & postoperative \\
infection & turkey & diagnosis & artery & time \\
protein & health & find & leave & complication \\
identify & medical & positive & right & undergo \\
strain & data & biopsy & diagnosis & technique \\
polymorphism & management & carcinoma & cause & 2 \\
sequence & literature & vitamin & due & operation \\
\hline
\end{tabular}


DEU FMD 22(64), 67-80, 2020

Tablo 11. 2016 yılına ait konular.

\begin{tabular}{lllll}
\hline Oksidatif stres & $\begin{array}{l}\text { Cerrahi tekniğin } \\
\text { sinirlere etkisi }\end{array}$ & $\begin{array}{l}\text { Ameliyat } \\
\text { kalp fonksiyonları }\end{array}$ & $\begin{array}{l}\text { sonrası } \\
\text { enfeksiyonları }\end{array}$ & Vaka, tümör \\
\hline rat & surgery & time & treatment & case \\
effect & surgical & blood & infection & report \\
tissue & technique & leave & hospital & present \\
increase & mean & pressure & mortality & diagnosis \\
stress & complication & postoperative & therapy & tumor \\
decrease & procedure & heart & rate & lesion \\
oxidative & nerve & cardiac & clinical & mass \\
control & follow-up & function & day & disease \\
activity & fracture & $\mathrm{v}$ & failure & cause \\
damage & perform & undergo & include & rare \\
\hline
\end{tabular}

Tablo 12. 2017 yılına ait konular.

\begin{tabular}{lllll}
\hline İlaç Çalışması & Göğüs kanseri & Gebelik & Çocuk hastalıkları & $\begin{array}{l}\text { Ameliyat } \\
\text { komplikasyonlar }\end{array}$ \\
\hline cell & cancer & number & case & surgery \\
activity & tumor & see & disease & postoperative \\
acid & lesion & observe & report & surgical \\
protein & case & pregnancy & clinical & technique \\
compound & breast & data & present & undergo \\
drug & stage & two & diagnosis & complication \\
show & survival & energy & child & perform \\
property & diagnosis & compare & syndrome & mean \\
effect & imaging & cycle & treatment & procedure \\
extract & carcinoma & high & symptom & fracture \\
\hline
\end{tabular}

Çıkartılan konular tıp doktoru tarafindan niteliksel olarak değerlendirilmiș ve etiketlenmiștir. Değerlendirmeler sonucunda modelin tıp makaleleri üzerinde oldukça başarılı bir şekilde çalıştığı, anlamlı konuların elde edildiği ve konuların kendi içerisinde tutarlı olduğu gözlemlenmiştir. Çıkartılan konuların yıllara göre özeti ise Tablo 13'te verilmiştir. 
DEU FMD 22(64), 67-80, 2020

Tablo 13. Konuların yıllara göre özeti.

\begin{tabular}{|c|c|c|c|c|c|}
\hline Yillar & Çalışma Konuları & & & & \\
\hline 2007 & Nöroloji & $\begin{array}{l}\text { Plazma } \\
\text { Sonuçları }\end{array}$ & Burun Hasarı & $\begin{array}{l}\text { Türkiye'deki } \\
\text { Virüsler }\end{array}$ & $\begin{array}{l}\text { Akciğer veya } \\
\text { Böbrek } \\
\text { Komplikasyonu }\end{array}$ \\
\hline 2008 & Kalp Damar Cerrahisi & $\begin{array}{l}\text { Gögüus } \\
\text { Kanseri }\end{array}$ & Gebelik & $\begin{array}{l}\text { Çocuklarda } \\
\text { kemik yașı }\end{array}$ & Genetik \\
\hline 2009 & Genetik & $\begin{array}{l}\text { Göğüs } \\
\text { Kanseri }\end{array}$ & $\begin{array}{l}\text { Ortopedik } \\
\text { operasyon }\end{array}$ & $\begin{array}{l}\text { Farelerle ilgili } \\
\text { çalışma }\end{array}$ & \\
\hline 2010 & Farelerle İlgili Çalışma & $\begin{array}{l}\text { Göğüs } \\
\text { kanseri }\end{array}$ & Genetik & $\begin{array}{l}\text { Gebelik, } \\
\text { Çocuklar }\end{array}$ & Cerrahi çalışma \\
\hline 2011 & Kalp Damar Cerrahisi & $\begin{array}{l}\text { Ortopedik } \\
\text { operasyon }\end{array}$ & $\begin{array}{l}\text { Türkiye'deki } \\
\text { gen çalışması }\end{array}$ & $\begin{array}{l}\text { Göğüs } \\
\text { kanserinin } \\
\text { görüntülenmesi }\end{array}$ & $\begin{array}{l}\text { Kronik böbrek } \\
\text { hastalığ }\end{array}$ \\
\hline 2012 & Genetik ve Gebelik & $\begin{array}{l}\text { Enfeksiyon } \\
\text { hastalıkları }\end{array}$ & $\begin{array}{l}\text { Yeni } \\
\text { doğanlarda } \\
\text { solunum } \\
\text { yetmezliği }\end{array}$ & $\begin{array}{l}\text { Göğüs kanseri } \\
\text { ve tiroit }\end{array}$ & $\begin{array}{l}\text { Mikrobiyolojik } \\
\text { ajanların } \\
\text { boyanması }\end{array}$ \\
\hline 2013 & Plastik Cerrahi & $\begin{array}{l}\text { Türkiye'deki } \\
\text { enfeksiyon } \\
\text { hastalıkları }\end{array}$ & $\begin{array}{l}\text { Görüntüleme } \\
\text { yöntemleri }\end{array}$ & Cerrahi çalışma & $\begin{array}{l}\text { Farelerle ilgili } \\
\text { çalışma }\end{array}$ \\
\hline 2014 & Cerrahi Teknik Sonrası Ağrı & $\begin{array}{l}\text { Öğrencilerde } \\
\text { depresyon }\end{array}$ & $\begin{array}{l}\text { Farelerle } \\
\text { ilgili çalışma }\end{array}$ & Kardiyoloji & Kanser \\
\hline 2015 & Gen Mutasyonları & $\begin{array}{l}\text { Türkiye'de } \\
\text { yapılan } \\
\text { çalışmalarla } \\
\text { ilgili bir özet }\end{array}$ & $\begin{array}{l}\text { Göğüs } \\
\text { kanseri }\end{array}$ & $\begin{array}{l}\text { Vaka (nadir } \\
\text { görülen) } \\
\text { çalışması }\end{array}$ & $\begin{array}{l}\text { Cerrahi teknik } \\
\text { sonrası ağrı }\end{array}$ \\
\hline 2016 & Oksidatif Stres & $\begin{array}{l}\text { Cerrahi } \\
\text { tekniğin } \\
\text { sinirlere } \\
\text { etkisi }\end{array}$ & $\begin{array}{l}\text { Ameliyat } \\
\text { sonrası kalp } \\
\text { fonksiyonları }\end{array}$ & $\begin{array}{l}\text { Hastane } \\
\text { enfeksiyonları }\end{array}$ & Vaka, tümör \\
\hline 2017 & İlaç Çalışması & $\begin{array}{l}\text { Göğüs } \\
\text { kanseri }\end{array}$ & Gebelik & $\begin{array}{l}\text { Çocuk } \\
\text { hastalıkları }\end{array}$ & $\begin{array}{l}\text { Ameliyat sonrası } \\
\text { komplikasyonlar }\end{array}$ \\
\hline
\end{tabular}

Tablo 13 genel olarak incelendiğinde 11 yıllık süreçte göğüs kanseri ve göğüs kanseri ile ilişkili konuların en sık araștırma yapılan başlıklar olduğu görülmüștür. 2009-2014 yılları arasında farelerle ilgili çalışmaların revaçta olduğu görülmektedir. 2013 yılı itibariyle cerrahi teknik ve ameliyat sonrası oluşan durumlar literatürde yer bulmaya başlamıştır. Genetik ve genetikle ilgili konular da gögüs kanseri gibi 11 yıldır neredeyse her yll çalışılmıștır. Gebelik ve gebelikle ilişkili konuların da araștırmacıların ilgi alanına girdiği yine Tablo 13 üzerinden varılan sonuçlardan birisi olmuştur. Sadece Türkiye'nin örnek vaka seçildiği çalışmalar da 11 yıllık süreçte çalışılan önemli başlıklardan biri olarak literatürde yerini almıştır.

\section{Tartışma ve Sonuç}

Bilimsel literatür her geçen gün hızlı bir ivme ile genişlemektedir. $\mathrm{Bu}$ büyük veri kümesi üzerinden bir yargıya varmak, hangi yıllarda hangi konuların ağırlıklı çalışıldığının tespit edilmesi ise insan gücü ile gerçekleștirilmesi zor bir görevdir. Tüm bu durumlar göz önünde 
DEU FMD 22(64), 67-80, 2020

bulundurulduğunda araștırmacılara katkı sağlamak ve yol gösterici olmak amacıyla 20072017 yılları arasında tıp alanındaki Türkiye'deki araştırmacılar tarafından oluşturulan literatür elde edilmiştir. Elde edilen literatür GDA'ya girdi olarak verilmiş ve sonucunda hangi yıllarda hangi konuların ağırlıklı çalıșıldığ tespit edilmiștir. Model hem niceliksel hem de niteliksel olarak değerlendirilmiş ve GDA'nın hem otomatik hem de anlamsal analiz açısından başarılı olduğu gözlemlenmiştir.

Çalışmamız bu anlamda Türk tıp literatürü için gerçekleștirilen ilk çalışma olup, tıp alanındaki

\section{Kaynakça}

[1] Schwarz, C. 2018. ldagibbs: A command for topic modeling in Stata using latent Dirichlet allocation, The Stata Journal, Cilt. 18, s. 101-117. DOI: $10.1177 / 1536867 X 1801800107$

[2] Sun, M., Zheng, H. 2018. Topic Detection for Post Bar Based on LDA Model. ss 136-149. Zhou, Q., Miao, Q. Wang, H., Xie, W., Wang, Y., Lu, Z., ed. 2018. Communications in Computer and Information Science, Springer Singapore, Singapore, 1396s.

[3] Shah, A.H. 2019. How episodic frames gave way to thematic frames over time: A topic modeling study of the Indian media's reporting of rape post the 2012 Delhi gang-rape, Poetics, Cilt. 72, s. 54-69. DOI: 10.1016/j.poetic.2018.12.001

[4] Karami, A., Ghasemi, M., Sen, S., Moraes, M.F., Shah, V. 2019. Exploring diseases and syndromes in neurology case reports from 1955 to 2017 with text mining, Computers in Biology and Medicine, Cilt 109, S. $\quad 322-332 . \quad$ DOI: 10.1016/j.compbiomed.2019.04.008

[5] Blei, D.M., Ng, A.Y. 2003. Latent dirichlet allocation, The Journal of Machine Learning Research, Cilt. 3, s. 993-1022.

[6] Agrawal, A., Fu, W., Menzies, T. 2018. What is wrong with topic modeling? And how to fix it using searchbased software engineering, Information and Software Technology, Cilt. 98, s. 74-88. DOI: 10.1016/j.infsof.2018.02.005

[7] Holzinger, A., Dehmer, M., Jurisica, I. 2014 Knowledge discovery and interactive data mining in bioinformatics: State-of-the-art, future challenges and research directions, BMC Bioinformatics, Cilt. 15 s. 1-9. DOI: 10.1186/1471-2105-15-S6-I1

[8] Lin, J.M., Bohland, J.V., Andrews, P., Burns, G.A.P.C., Allen, C.B., Mitra, P.P. 2008. An Analysis of the Abstracts Presented at the Annual Meetings of the Society for Neuroscience from 2001 to 2006, PLoS One, Cilt. $3, \quad$ s. $1-9 . \quad$ DOI: 10.1371/journal.pone.0002052

[9] Bundschus, M., Tresp, V., Kriegel, H.P. 2009. Topic Models for Semantically Annotated Document Collections. NIPS Workshop: Applications for Topic Models: Text and Beyond, 7-10 Aralık, Whistler, 1-4.

[10] Jiang, Z., Zhou, X., Zhang, X., Chen, S. 2012. Using Link Topic Model to Analyze Traditional Chinese araștırmacılara fikir olușturması açısından, oldukça önemlidir. Ayrıca, elde edilen konular üzerinden hangi hastalıkların ülkemizde 11 (on bir) yıl içerisinde sık görüldüğü ve önlem alma açısından hangi konuların daha çok göz önünde bulundurulması gerektiğinin tespiti açısından da çalışma oldukça değerlidir.

\section{Teşekkür}

Modelin niteliksel değerlendirilmesi ve konuların etiketlenmesi aşamasında bize her türlü yardımda bulunan Kocaeli Üniversitesi Tıp Fakültesi Gögüs Hastalıkları Bölümü'nden Doç. Dr. Haşim Boyacı Hocamıza teşekkürlerimizi sunarız.

Medicine Clinical Symptom-Herb Regularities. 2012 IEEE 14th International Conference on e-Health Networking, Applications and Services (Healthcom), 10-13 Ekim, Pekin, 15-18.

[11] Redfield, C.K., Lou, X., Karaletsos, T., Crosbie, C., Gardos, S., Artz, D., Ratsch, G. 2013. An empirical analysis of topic modeling for mining cancer clinical notes. 2013 IEEE 13th International Conference on Data Mining Workshops, 7-10 Aralık, Dallas, 56-63.

[12] Cui, M., Liang, Y., Li, Y., Guan, R. 2015. Exploring Trends of Cancer Research Based on Topic Model. 1st International Workshop on Semantic Technologies, 9-12 Mart, Changchun, 7-18.

[13] Beykikhoshk, A., Arandjelović, O., Venkatesh, S., Phung, D. 2015. Hierarchical Dirichlet Process for Tracking Complex Topical Structure Evolution and Its Application to Autism Research Literature. ss 550-562. Cao, T., Lim, E.P., Zhou, Z.H., Ho, T.B., Cheung, D., Motoda, H., ed. 2015. Advances in Knowledge Discovery and Data Mining, Springer Cham, Switzerland, 763s.

[14] Song, M., Heo, G.E., Lee, D. 2015. Identifying the landscape of Alzheimer's disease research with network and content analysis, Scientometrics, Cilt. 102, s. 905-927. DOI: $10.1007 /$ s11192-014-1372-x

[15] van Altena, A.J., Moerland, P.D., Zwinderman, A.H., Olabarriaga, S.D. 2016. Understanding big data themes from scientific biomedical literature through topic modeling, Journal of Big Data, Cilt. 3, s. 1-21. DOI: $10.1186 / s 40537-016-0057-0$

[16] Speier, W., Ong, M.K., Arnold, C.W. 2016. Using phrases and document metadata to improve topic modeling of clinical reports, Journal of Biomedical Informatics, Cilt. 61C, S. 260-266. DOI: 10.1016/j.jbi.2016.04.005

[17] Hahn, A., Mohanty, S.D., Manda, P. 2017. What's Hot and What's Not? - Exploring Trends in Bioinformatics Literature Using Topic Modeling and Keyword Analysis. ss 279-290. Cai, Z., Daescu, O., Li, M., ed. 2017. Bioinformatics Research and Applications, Springer Cham, Switzerland, 499s.

[18] Drosatos, G., Kavvadias, S.E., Kaldoudi, E. 2018. Topics and Trends Analysis in eHealth Literature. ss 563-566. Eskola, H., Väisänen, O., Viik, J., Hyttinen, J., ed. 2018. IFMBE Proceedings, Springer Singapore, Singapore, 1139s. 
DEU FMD 22(64), 67-80, 2020

[19] Steyvers, M., Griffiths, T. 2007. Probabilistic Topic Models. ss 1-15. Landauer, T., McNamara, D.S. Dennis, S., Kintsch, W., ed. 2007. Handbook of Latent Semantic Analysis: A Road to Meaning, Psychology Press, USA, 544s.

[20] Lu, Y., Mei, Q., Zhai, C.X. 2011. Investigating task performance of probabilistic topic models: an empirical study of PLSA and LDA, Information Retrieval, Cilt. 14, s. 178-203. DOI: 10.1007/s10791010-9141-9

[21] Blei, D.M. 2012. Probabilistic Topic Models, Communucations of the ACM, Cilt. 55, s. 77-84. DOI: $10.1145 / 2133806.2133826$

[22] Deerwester, S., Dumais, S.T., Furnas, G.W., Landauer, T.K., Harsman, R. 1990. Indexing by Latent Semantic Analysis, Journal of the American Society for Information Science, Cilt. 41, s. 391-407. DOI: 10.1002/(SICI)1097-4571(199009)41:6<391::AIDASI $1>3.0 . C 0 ; 2-9$

[23] Hoffman, T. 1999. Probabilistic Latent Semantic Analysis. Fifteenth Conference on Uncertainty in Artificial Intelligence, 20 Temmuz-1 Ağustos, Stockholm, 289-296.

[24] Popescul, A., Ungar, L., Pennock, D., Lawrence, S. 2001. Probabilistic models for unified collaborative and content-based recommendation in sparse-data environments. 17th Conference in Uncertainty in Artificial Intelligence, 2-5 Ağustos, Washington, 437 444.

[25] Ng, K.W., Tian, G.L., Tang, M.L. 2011. Dirichlet and Related Distributions: Theory, Methods and Applications. Wiley, New York, 337s.

[26] Ekinci, E., İlhan Omurca, S. 2018. An AspectSentiment Pair Extraction Approach Based on Latent Dirichlet Allocation for Turkish, International Journal of Intelligent Systems and Applications in Engineering, Cilt. 6, s. 209-213. DOI: 10.18201/ijisae.2018644779

[27] Ekinci, E., İlhan Omurca, S. 2017. Ürün Özelliklerinin Konu Modelleme Yöntemi ile Çıkarılması, Türkiye Bilişim Vakfı Bilgisayar Bilimleri ve Mühendisliği Dergisi, Cilt. 9, s. 51-58.

[28] Ekinci, E., İlhan Omurca, S. 2019. Concept-LDA: Incorporating Babelfy into LDA for aspect extraction, Journal of Information Science. DOI: $10.1177 / 0165551519845854$

[29] Griffiths, T.L., Steyvers, M. 2004. Finding Scientific Topics, Proceedings of the National Academy of Sciences of the United States of America, Cilt. 101, s. 5228-5235. DOI: 10.1073 /pnas.0307752101

[30] Mimno, D., Wallach, H.M., Talley, E., Leenders, M. McCallum, A. 2011. Optimizing semantic coherence in topic models. Conference on empirical methods in natural language processing, 27-31 Temmuz, Edinburgh, 262-272.

[31] Newman, D., Lau, J.H., Grieser, K., Baldwin, T., McCallum, A. 2010. Automatic evaluation of topic coherence. The 2010 Annual Conference of the North American Chapter of the Association for Computational Linguistics, 2-4 Haziran, California, 100-108.

[32] Atıcı, B., İlhan Omurca, S., Ekinci, E. 2017. Kullanıc Şikayetlerindeki Ürün Özelliklerinin Gizli Dirichlet Ayırımı ile Saptanması. 2017 Uluslararası Bilgisayar
Bilimleri ve Mühendisliği Konferansı, 5-8 Ekim, Antalya, 250-254. 